\title{
Microfinance and Poor: A Case Study of District Sangrur
}

\author{
Gagandeep Kaur Gill \\ Department of Social Sciences \\ Punjabi University Patiala \\ Punjab, India
}

Received: October 28, 2014 Accepted: December 3, 2010 Published: December 29, 2014

doi:10.5296/ijrd.v1i1.6520 URL: http://dx.doi.org/10.5296/ijrd.v1i1.6520

\begin{abstract}
Microfinance has become a effective way to economically and socially empowering the poor in developing countries like India. This research paper finds the effectiveness of the microfinance policy adopted by Non government Organization Umeed Foundation, effectively working in district Sangrur, on rural poor households. In our research we tries to find out whether this policy has any effect on income, expenditure and savings of beneficiary household. Two blocks Bhawanigarh and Sangrur blocks were purposely selected where from 12 villages data was collected from 200 beneficiaries of 18 Self Help Groups. We used closed ended questionnaire and personally met the beneficiaries and discussed the questions in details. All the respondents from whom data were the members of Self Help groups formed under foundation. All the beneficiaries were women. Mostly these beneficiaries were illiterate and belonged to schedule cast. Beneficiaries borrowed under scheme to invest in productivities but only 80 percent did so. Repayment rate is very high in our research. T- Test is applied to statistically analyse the data. Research found that Umeed Foundation is very popular among the poor and there is positive impact of scheme on income, expenditure and savings of the beneficiary household.
\end{abstract}

Keywords: Non government organisations, Self Help Groups, Umeed foundation

\section{Introduction}

Developing countries have been facing a number of problems and among them poverty is a major one that hinders the growth of a county. If it is not controlled and eradicated, it results in further poverty thus making a vicious circle and also becomes the cause of many other social evils. It can be defined as "poverty is a situation where a section of a society, having no fault of their own, is denied of even basic necessities of life. In a country, where a big chunk 
of population is deprived of even minimum amenities of life for a very long period, the country will then suffer from a vicious circle of poverty" (Dhar 2007). About one billion population worldwide is living less than US \$ 1.25 a day (World Bank Annual Report 2013). In India about 269.3 million (21.9\%) (Govt. of India: Planning Commission July 2013) population is still living below poverty line. In order to get the poor out of poverty many policies have been made, many schemes have been implemented and many tools have been adopted time to time. But one of the effective tools among all, applied is microfinance. Microfinance policy was given a new shape by Dr. Muhammad Yunus who designed a credit program to serve the poor with his graduate students in Chittagong University in 1972. This piloted programme was later named as Grameen Bank in 1983. In 2006 Nobel Foundation awarded its Nobel Prize to Dr. Muhammad Yunus and his Grameen bank. Moreover, this credit program has become a model for most of the low income countries which are actively engaged in the process of eradicating poverty from their soil. So microfinance is a scheme implemented through Self Help Groups to provide the poor financial assistance while taking their difficulties into account. Moreover, this credit program has become a model for most of the low income countries which are actively engaged in the process of eradicating poverty from their soil.

Microfinance is a financial service of small quantity provided by financial institutions such as banks, NGOs, MFI's etc, to the poor. These financial services may include savings, credit, insurance, leasing, money transfer, equity transfer etc, that is, any type of financial service provided to customers to meet their normal financial needs. "Microcredit, or microfinance, is banking the unbankables, bringing credit, savings and other essential financial services within the reach of millions of people who are too poor to be served by regular banks, in most cases because they are unable to offer sufficient "collateral." Maanen et. al. (2004).

\section{Objectve of Study}

Objective of paper is to analyse the impact of microfinance on rural poor. So we have taken three variables into account to find out the impact and these are:

-Average monthly Income of household;

-Average monthly expenditure of household;

-Average monthly saving of household;

-Average monthly consumption expenditure.

In the research paper mainly the objective is to find what is the impact of microfinance and we have tried to analyse whether the scheme has been benefiting the poor.

\section{Literature Review}

Many studies had been conducted in this field. But our study is conducted in Sangrur a backward district of Punjab and where no similar study was undertaken. Study by Okibo and Makanga (2014) found that microfinance institutions are useful tools for poverty reduction. It has improved the standard of living of clients. Berhane and Gardebroek (2012) attempted to 
assess the long term impact of microfinance and found that participants had benefited in terms of broader socio-economic aspects, such as health and education of their children and long-term participants enjoyed relatively higher average annual consumption than short-term participants. Study by Kundu (2008) on SHGs under Swarna Jayanti Grameen Swarojgar Yojana (SGSY) shows that SGSY is helping the rural poor to reduce their poverty but still fails to reduce their vulnerability. Westover's (2008) study, based on some previous case studies found increased household income, improved healthcare, nutrition, education and empowered women and also broke down the gender inequalities. The study by Mawa (2008) shows the positive impact of microfinance on poverty reduction. Kondo et. all (2008) in his study found that availing of programme loans had positive but mild significant impacts on per capita household income, per capita expenditures are also positively affected by a family's access to program loans. There is no significant impact of loan on saving. It was found that mostly the clients werenot poor and the microfinance had negative impact on poor households and positive on rich households. Karnani (2007) found that although microcredit yields some noneconomic benefits, it does not significantly alleviate poverty. He characterizes the poor as mostly entrepreneurial failures. Impact assessment study of microfinance by Sarangi (2007) shows a positive and significant effect of programme participation on increase in the income of the household. However, the impact is negligible for the households at the lower end of income. It is not helping the very poor. Sekhri (2007) has reviewed that although microfinance has been proved a powerful poverty alleviation tool yet after more than 30 years of industry effort, 80 percent of the working poor is still without access to microfinance. MFIs are facing some problems such as lack of capital to grow, lack of large scale internal operation capacity, regional imbalances, efficient technology. Vasimalai (2007) has attempted to explain the Kalanjiam programme promoted by DHAN foundation in 8 states of India and 55 percent members of more than five years old reported improved housing condition after joining the programme. In terms of women empowerment, 80 percent women members had developed skills to solve issues at family, In terms of saving around 72 percent members saved Rs. 100 per month and the saving rate increased as the age of Kalanjiam increased. Tefera (2007) carried out a research on goat proect in eastern Ethiopia and pointed out that goat credit project has shown a marked success at raising living standards and Improving housing condition of women farmers were observed.

\section{Methodology}

\subsection{Study Area}

Study was conducted in Sangrur, one of the four districts in Patiala Division and a backward district of Punjab (India). Umeed the largest foundation was working to raise the lives of poor and was famous among the poor in Sangrur. The focus was to analyse the effectiveness of the foundation and it was spread in Sangrur. So district Sangrur was selected for survey. This foundation was founded by Mr. Arvind Khanna in 1997 and registered in March under Indian Trust Act 1882. Main aim of the foundation is to provide healthcare facilities and improving the lives of under privileged through social and economic empowerment. Projects of Umeed had reached out to 550 villages and benefitting people of diverse communities. For rural development, dairy, stitching, embroidery, running shop, leather work, primary healthcare, 
bag making, pickle making, book binding, compost gas and horticulture projects has been started. Projects of foundation has been implemented through Self Help Groups. A Self Help Group is a group of people who provide mutual support to each other. In other words it typically comprises a group of micro entrepreneurs having homogeneous social and economic backgrounds, all voluntarily coming together to save regular small sums of money, mutually agreeing to contribute to a common fund and to meet their emergency needs on the basis of mutual help. They come together for addressing their common problems.

\subsection{Conditions of Forming Shgs}

1). No. of members in a group range from 10 to 20 ;

2). Group members are taken from similar economic strata;

3). Only one member of family can be a member of SHG;

4). Minimum age limit to be a member is 18 to 20 years.

In order to analyzing the impact on beneficiaries of Umeed foundation two blocks i.e Bhawanigarh and Sangrur were selected purposely. Further 12 villages are purposely selected where SHG were actively working for more than one year.

\subsection{Data Collection}

Research is wholly based on primary data. In order to collect the primary data first we conducted Pilot survey and then Field survey. Time period of study was August 2012-October 2012. Sample size for the study was 200 beneficiaries. We selected 18 Self Help Groups comprising 200 member women. A detailed questionnaire was prepared to collect the information from the beneficiaries. In this questionnaire close ended questions are used in which options were given and respondents had to give their answer in those options. We personally approached the beneficiaries with the help of workers of Umeed Foundation who are managing the Self Help Groups. We discussed the questions with them and recorded their responses on printed questionnaire. First section of the questionnaire is about the demographic profile of beneficiaries. In the second segment questions were related to the borrowings and third segment focused on income, expenditure and savings of beneficiary household.

\subsection{Data Analysis}

Data was collected from 200 beneficiaries through printed questionnaire. The response rate was $100 \%$. In order to find the statistical results Mean, Standard deviation and paired T-Test is applied on data. Table 1 is the demographic profile of the respondents. Table 2 compile the responses of respondents regarding type of loan taken, loan Investment, loan installments and other sources of finances. Table 3 represents average monthly income earned from different productive activities started under the scheme. Table 4 and Table 5 is about Mean, S.D and Paired T-Test analysis summary where Table 6 represents the change in consumption expenditure of beneficiaries households after joining the group. 


\section{Macrothink}

\section{Results and Discussions}

Table 1. Demographic profile of the beneficiaries

\begin{tabular}{|c|c|c|}
\hline Variables & frequency & Percent \\
\hline \multicolumn{3}{|l|}{ Gender } \\
\hline Male & 0 & 0 \\
\hline Female & 200 & 100 \\
\hline \multicolumn{3}{|l|}{ Age } \\
\hline$<20 \mathrm{yrs}$ & 10 & 5 \\
\hline $20-40 y r s$ & 114 & 57 \\
\hline$>40 \mathrm{yrs}$ & 76 & 38 \\
\hline \multicolumn{3}{|l|}{ Social group } \\
\hline General & 28 & 14 \\
\hline Schedule cast & 172 & 86 \\
\hline \multicolumn{3}{|l|}{ Education } \\
\hline Illiterate & 125 & 62.5 \\
\hline Upto $5^{\text {th }}$ & 36 & 18 \\
\hline Upto $10^{\text {th }}$ & 34 & 17 \\
\hline $10+2$ and above & 5 & 2.5 \\
\hline \multicolumn{3}{|c|}{ Family Occupation } \\
\hline Farming & 17 & 8.5 \\
\hline Labour & 127 & 63.5 \\
\hline Housewife & 31 & 15.5 \\
\hline Service & 25 & 12.5 \\
\hline
\end{tabular}

Data was collected from 200 beneficiaries through detailed questionnaire. Table 1 is the demographic profile of the respondents. All the beneficiaries interviewed were women. The highest number of members i.e.57\% were between 20-40 years old which the most productive age period is. $86.5 \%$ respondents belonged to schedule cast social group where only $14 \%$ were belong to General social group. Education level was not the matter while becoming the member of SHGs because majority of the beneficiaries consulted i.e $63.5 \%$ were illiterate. It was seen that mostly $63.5 \%$ respondents were from that family whose main occupation is labour or main source of earning is wage. 
Table 2. Distribution of Type of loan taken, loan Invested, loan installment and other Sources of Finances

\begin{tabular}{|l|l|l|l|}
\hline Measuring group & Variables & Frequency & Percent \\
\hline \multirow{4}{*}{ Purpose of loan taken } & Dairy & 127 & 63.5 \\
\cline { 2 - 4 } & Shop & 18 & 9.0 \\
\cline { 2 - 4 } & Stitching & 25 & 12.5 \\
\cline { 2 - 4 } & Knitting & 160 & 15 \\
\hline \multirow{2}{*}{$\begin{array}{l}\text { Use of loan for the purpose for which } \\
\text { it was taken }\end{array}$} & Yes & 47 & 80.0 \\
\cline { 2 - 4 } & No & 200 & 200.0 \\
\hline Paying instalments & Yes & - & - \\
\cline { 2 - 4 } & No & 27 & 13.5 \\
\hline \multirow{2}{*}{ Finance from other sources } & Yes & 173 & 86.5 \\
\cline { 2 - 4 } & No & & \\
\hline
\end{tabular}

Table 2 is all about the borrowings. All the beneficiaries borrowed under scheme for productive purpose where 63.5 percent borrowed to invest in dairy, 9 percent in grocery shop, 12.5 percent in stitching, 15 percent in knitting but only 80 percent invested in these income generating activities and rest 20 percent used for non productive purpose such as consumption, ceremonies or paying old debt. Repayment rate was very high i.e 100 percent. There was not any information of breaking up of SHG and all members of SHGs are working peacefully. All the beneficiaries were attending the meeting twice a month conducted by workers of Umeed where they discuss their problems. Instalments were paid monthly. Beneficiaries of stitching and knitting were given training by trainers appointed through Foundation. Only 13.5 percent clients, after becoming the member, borrowed from zamindars, relatives etc. Mainly these members were those who used loan for non productive purpose.

Table 3. Average Monthly Income from Different activities undertaken under scheme

\begin{tabular}{|l|l|l|}
\hline Activity & $\begin{array}{l}\text { Total monthly Income } \\
\text { from Microfinance in } \\
\text { Rs. }\end{array}$ & $\begin{array}{l}\text { Average monthly income } \\
\text { from Microfinance in Rs. }\end{array}$ \\
\hline Dairy & 138550 & 1489.785 \\
\hline Stitching & 52950 & 2521.43 \\
\hline Shop & 42200 & 2637.5 \\
\hline Knitting & 39200 & 1400 \\
\hline
\end{tabular}

Table 3 comprised of the details of income generated from activities started by the beneficiaries after joining the groups. Average income from Dairy was Rs. 1489.785 and from Stitching of cloths it was Rs.2521.43. Average income from grocery shop was Rs. 2637.5 and from knitting it was Rs. Rs. 1400.Study found that Grocery shop was more 
income generating than any other activity where as knitting was earning less because of less demand for handmade woolens.

Table 4. Mean, SD and t ratios for average monthly income and expenditure of beneficiary household

\begin{tabular}{|c|c|c|c|c|c|c|c|}
\hline \multirow[b]{2}{*}{ Measuring Group } & \multicolumn{2}{|c|}{ Before SHG } & \multicolumn{2}{|c|}{ After SHG } & \multirow{2}{*}{$\mathrm{t}$ value } & \multirow{2}{*}{ Df } & \multirow{2}{*}{$p$ value } \\
\hline & Mean & $\mathrm{SD}$ & Mean & $\mathrm{SD}$ & & & \\
\hline Average income month & 5324.0 & 3124.9 & 6699.0 & 3144.5 & -24.6 & 199 & $0.00 * *$ \\
\hline $\begin{array}{l}\text { Average expenditure } \\
\text { month }\end{array}$ & 5526.0 & 3049.1 & 6767.7 & 3056.5 & -28.4 & 199 & $0.00 * *$ \\
\hline
\end{tabular}

Note: $* *$ denote significant at $0.01 \%$ level.

Table 4 is the details of average monthly average income from all sources and overall expenditure by beneficiary households. Significant mean difference $(\mathrm{t}=-24.6, \mathrm{p}<0.01)$ on monthly average income shows increase in income of beneficiary household after investing in productive assets. Significant mean difference $(\mathrm{t}=-28.4, \mathrm{p}<0.01)$ on monthly average expenditure shows positive change in expenditure.

Table 5. Mean, SD and t ratio for average monthly saving of beneficiary household

\begin{tabular}{|l|l|l|l|l|l|l|l|}
\hline & \multicolumn{2}{|l|}{ Before SHG } & \multicolumn{2}{l|}{ After SHG } & $\begin{array}{l}\mathrm{t} \\
\text { value }\end{array}$ & Df & $\begin{array}{l}\mathrm{p} \\
\text { value }\end{array}$ \\
\cline { 2 - 9 } Measuring Group & Mean & SD & Mean & SD & & & \\
\hline Savings of Household & -195 & 254.9 & -61.8 & 302.3 & -6.69 & 199 & $0.00^{* *}$ \\
\hline
\end{tabular}

Note: $* *$ denote significant at $0.01 \%$ level

Table 5 is about the savings of households. Significant mean difference was found on average monthly saving of household ( $\mathrm{t}=-6.69, \mathrm{p}<0.01)$ before joining SHG and after joining SHGs. $33.75 \%$ were saving on an average upto Rs. 100/month. Income expenditure gap of $61.25 \%$ beneficiaries had reduced and income expenditure gap of $48.75 \%$ had reduced to zero.

Table 6. Change in average monthly consumption expenditure of beneficiary household

\begin{tabular}{|l|l|l|}
\hline Measuring group & Frequency & Percent \\
\hline No change & 61 & 30.5 \\
\hline Increased & 100 & 50.0 \\
\hline Decreased & 39 & 19.5 \\
\hline Total & 200 & 100.0 \\
\hline
\end{tabular}

Table 6 is details of monthly consumption expenditure (food items). In consumption 
expenditure vegetables, cereals, edible oil, flour, spices, milk, fruits, milk products, meat, fuel, gas etc are included. $30.5 \%$ beneficiaries did not show any change in consumption expenditure, $50.0 \%$ beneficiaries showed increase in consumption expenditure and $19.5 \%$ beneficiaries showed decrease in consumption expenditure. Average net expenditure on food items increased upto Rs. 150/month.

\section{Conclusion}

Our research was on analyzing the impact of microfinance on the beneficiaries of Self Help Groups of Umeed Foundation in district Sangrur. And for this purpose we considered variables such as income, expenditure, consumption expenditure and savings were considered. Data was collected from 200 beneficiaries of SHGs. Umeed Foundation has become very popular among the rural poor of district. It was found that scheme is positively benefiting the poor. It had positive impact on income, expenditure and savings of the beneficiaries. Repayment rate was very high and all the groups were working peacefully. There was no news of breaking up of any SHG. Beneficiaries who had taken up stitching and knitting activities were given training by the trainers of Umeed Foundation. Beneficiaries reported that after joining the groups they had easy access to credit. We consider only those beneficiaries who were in the scheme not more than one and half year and not less than one year and during these span positive results were found. So as the debt would be repaid totally, more change would be witnessed. It was also found that the scheme still has not been covering the destitute.

\section{Limitations of the Study}

Although our results are satisfactory, yet we considered only those beneficiaries who are benefiting from the scheme not more than one and half year. Our sample size was small so large sample can be taken for further research. We only taken into account income, expenditure and savings and there are many other factors left which can be consider further. As we are limited to two blocks of the district so the results cannot be generalized to the whole microfinance industry and on other parts of the country because of the differences in the working conditions, abilities, and interests of the communities.

\section{References}

Berhane \& Gardebroek. (2012). Assessing the Long-term Impact of Microcredit on Rural Poverty: Does the Timing and Length of Participation Matter? Ethiopia Strategy Support Program II, Working Paper, 43.

Dhar, P. K. (2007). Indian Economy and Its Growing Dimensions (15th ed.). Ludhiana: Kalyani Publishers.

Karnani, A. (2007). Microfinance Misses its Mark. Stanford Social Innovation Review, 5(3), 34-40.

Kondo, T., Orbeta, A., dingcong, C., \& Infantado, C.(2008). Impact of microfinance on rural households in the Philippines. PIDS Discussion Paper Series No. 2008-05. [Online] Available: http:/www.adb.org/Documents/SES/REG/SST-REG-2007-19/SST-REG-2007-19.asp 
Kundu, A. (2008). Impact of SGSY Scheme on Self-Help Group Members in West Bengal. Afro Asian Journal of Rural Development, 41(2), 83-104.

Maanen, H., \& Oikocredit. (2004) Microcredit Sound business for Development Instrument. [Online] Available: http://www.microfinancegateway.org/sites/default/files/mfg-en-paper-microcredit-sound-busi ness-or-development-instrument-sep-2004.pdf

Mawa, B. (2008). Impact of Microfinance: Towards Achieving Poverty Alleviation. Pakistan Journal of Social Sciences. 5(9), 876-882

Okibo, B. W., \& Makanga, N. (2014). Effects of micro finance institutions on poverty reduction in Kenya. International Journal of current Research and Acdemic Review, 2(2), 76-95

Sarangi, N. (2007). Microfinance and the rural poor: A Study of Group-Based Credit Programmes in Madhya Pradesh India. Doctoral diss, Jawahar Lal Nehru University, New Delhi. [Online] Available: http://www.hss.iitb.ac.in/ties07/paper/ts4/psB/2.pdf

Sekhri, V. (2007). Growth and Challenges Faced in Microfinance: Trends and Future Outlook. Journal of IMS Group, 3(1).

Swain, R. B., \& Wallentin F. Y. (2007). Does Microfinance Empower Women? Evidence from Self Help Groups in India. International Review of Applied Economics, 23(5), 541-556. http://dx.doi.org/10.1080/02692170903007540

Tefera, T. (2007). Improving Women Farmers Welfare through a Goat Credit Project and Its Implications for Promoting Food Security and Rural Livelihoods. Journal of Rural and Community Development, 2(2), 123-129.

Vasimalai, N. (2007). Microfinance for Poverty Reduction: The Kalanjiam Way. Economic and Political Weekly, 42(13).

Westover, J. (2008). The record of microfinance: The Effectiveness/Ineffectiveness of Microfinance Programme as a Means of Alleviating Poverty. Electronic Journal of Sociology, 12(1).

\section{Copyright Disclaimer}

Copyright for this article is retained by the author(s), with first publication rights granted to the journal.

This is an open-access article distributed under the terms and conditions of the Creative Commons Attribution license (http://creativecommons.org/licenses/by/3.0/). 